\title{
Measuring Sufficiency of Social Insurance in Maintaining Quality of Life of Civil Pensioners in Pakistan
}

\author{
Muhammad $\operatorname{Jafar}^{1}{ }^{*}$, Aisha Shoukat ${ }^{2}$, and Farhat Ullah ${ }^{3}$
}

\begin{abstract}
The global economic crisis in 2007 has given new impetus to the debate on social protection as an instrument for addressing worldwide poverty and vulnerability. Pakistan has several social protection programmes in place, but they are primarily skewed towards formal sector economy. Social protection can be contributory (social insurance) or non-contributory (social assistance). This paper attempts to measure sufficiency of social insurance benefits for civil pensioners in maintaining quality of life $(Q O L)$ in term of food, health and housing. Adopting quantitative approach, data were collected from 358 respondents from province of Punjab through structured questionnaire. The data were analysed using SPSS whereas descriptive statistics and Pearson Corelation analysis were performed. The results show that social insurance benefits (monthly pension and gratuity) were playing critical role in maintaining QOL of civil pensioners. Furthermore, results of correlation analysis revealed that all three domains of QOL were significantly correlated with social insurance benefits. The study concludes that overall QOL of the civil pensioners was better than pensioners of private sector or elderly citizens (non-pensioners) from economically poor background. The study provides an insight for social workers, policy makers and stakeholders for influencing policy making and social planning for redesigning and revising social insurance programmes in Pakistan.
\end{abstract}

Keywords: Social insurance; Civil pensioners; Social protection; Quality of life; Pakistan.

\section{Introduction}

The economic crisis of 2007 resulted into increased poverty ratio across the globe, resultantly governments and international funding agencies started to consider policies aiming at welfare of the victims of poverty (Deacon, 2013 as cited by Zahid \& Whiteford, 2021). In the wake of this global economic crisis, debate on social protection has attracted the attention of researchers and policy makers as social protection has proved to be an effective instrument for addressing poverty and reducing economic vulnerability (Barrientos, 2010; Barrientos \& Hulme, 2009). Social protection measures are designed and

\footnotetext{
1 Department of Social Work, The Islamia University of Bahawalpur, Punjab, Pakistan.

2 Department of Social Work, The Islamia University of Bahawalpur, Punjab, Pakistan.

${ }^{3}$ Department of Social Work \& Sociology, Kohat University of Science \& Technology, Kohat, KP, Pakistan.
}

*)Corresponding Author.

Email: jaffarwattoo@gmail.com 
undertaken for reducing severity of economic shocks which can adversely affect QOL of individuals, groups and communities (ShuHong, 2017).

The concept of social security is not new, as it has been enshrined in Article 22 of the Universal Declaration of Human Rights of 1948. Social protection is an umbrella term which includes both social insurance and social assistance (Barrientos, 2006; Government of Pakistan, 2008 \& Weigand \& Grosh, 2008). Social insurance, a contributory and work-related entitlement, is different from social assistance which is means tested anti-poverty programmes (Tamborini $\&$ Cupito, 2012). Social insurance aims at protection of vulnerable household and families from falling into poverty when they are unable to maintain their income due to several factors including old age, disability and/or death (DeWitt, 2010). By design, social insurance benefits are designed to replace a significant proportion of the beneficiary's normal income (Midgley, 2009).

Historically, economic security has been primary and fundamental concern of human being since ages. The concept of economic security incorporates certain initiatives undertaken by individual and society for saving the person or family from falling below poverty line and being able to sustain minimum acceptable QOL. A survey of the literature divulges that different societies undertook various initiatives for provision of social protection to poor and vulnerable population. The measures for economic security included philanthropy, government funded programmes and need based family and community support.

In the South Asian region, none of the countries has an efficient and overarching social protection mechanism despite that fact that it is home to largest population in the world. That is why, much of the population in this region is highly insecure against social risks and economic vulnerability. Pakistan is no exception which is facing multiple challenges to provide sufficient and adequate social protection coverage to its working class particularly those working in informal economy. Although several programmes have been undertaken for provision of social protection, but it cannot be claimed that there is comprehensive social protection to all of its citizens. Lack of provision of social protection is against constitutional guarantee promised to all of the citizens (ShuHong et al., 2017).

Pakistan is home to more than 220 million people which makes it 5th most populous country in the world (The World Bank, 2021). The ratio of elderly population (dependent for their basic needs) is nearly $8 \%$ which has been estimated to increase in the coming years in Pakistan (Chohan, 2021). Only a small percentage of elderly population is covered by public or private social protection programmes, whereas vast majority remains out of the brackets of any such coverage because there is no social protection coverage for elderly or retirees of informal economy (Ashiq \& Asad, 2017).

Based on its vitality for overcoming poverty, Government of Pakistan gives central importance to social protection programmes for uplifting poor households and giving economic support to households and families living at the edge of poverty line (Azeem et al., 2019). The current study aims 
measuring sufficiency of social insurance for maintaining QOL of civil pensions in the province of Punjab.

\section{Beginning of Social Insurance at Global Level}

Globally, social insurance appeared in nineteenth and twentieth century as result of politico-economic changes. This era is characterized by fast industrialization throughout Europe which was followed by mass migration from rural areas to urban centres. At the same time, on political fronts, national states (with democracy as system of government) were coming into existence and traditional kingdoms were disappearing from the scenario (Feldstein \& Liebman, 2002). Changing socio-economic and political changes triggered need for and importance of social protection, that is why effective policies were framed for its sufficient provision. The new governments undertook social protection as a state responsibility.

For the first time, social insurance began in Europe in 1890s. Afterwards, this programme was introduced in other continents for safeguarding civil servants. Initially, social insurance was meant to cover three categories of beneficiaries including those lost earning due to old age, disease or disability. Two major happenings including Great Depression (1929-1939) and World War II (1939-1945) are considered hallmarks in the history of social protection programmes. The given socio-economic scenario required comprehensive and collective measures for befitting response to social risks which emerged during 1930s and 1940s. Collectively, all these circumstances lead towards all-inclusive social protection programmes (Dixon, 2001).

United States of America enacted social security act in August 1935 to provide social insurance to its retired employees along with many other general welfare provisions (DeWitt, 2010).

Table 1

Constituent Parts of Social Security Scheme

Constituent part Principal aspects for which indicators can be established

\begin{tabular}{ll}
\hline Coverage & Personal (legal) coverage: contributing and insured persons, beneficiaries \\
& Traditional contingencies: old-age, maternity, disability, health costs, \\
& survivors, employment injury, family, unemployment and subsistence \\
Benefits & Conditions of entitlement: personal coverage, contribution history, \\
& income and assets and definition of contingency \\
& Level of benefits: flat-rate, earnings-related (subject to ceiling) \\
Financing & Sources of financing: state subsidies, employers and workers' \\
& contributions, contributions a beficiaries \\
& Level of contribution: flat-rate or earnings-related (subject to ceiling)
\end{tabular}




\begin{tabular}{ll}
\hline Administration & $\begin{array}{l}\text { Delivery of benefits: prompt and accurate payment, awareness of } \\
\text { entitlement } \\
\text { Contribution }\end{array}$ \\
& $\begin{array}{l}\text { Organization and management: public-private mix } \\
\text { compliance }\end{array}$ \\
& efficiency and \\
&
\end{tabular}

Source: van Ginneken (2003)

Social protection programmes in global south region encounters several problems such as scarce financial resources and incapacitation of institutions is responsible for poor provision of social protection. On whole, these weaknesses limit coverage and efficiency of social protection programmes (Mumtaz \& Whiteford, 2017).

In the South Asian countries, social protection is largely based on kin and non-kinship relations because of strong relationships within joint and extended family and community at large (Guhan, 1992). Kabeer, Mumtaz and Sayeed (2006) asserted that economies in South Asian countries were mainly based on agricultural activities which are characterized by close familial and social ties. Based on well knitted social structure, close relatives, tribe members and neighbourers were main source of social protection. However, replacement of agricultural economy with industrialization and popularity of nuclear family system instead of joint family system weakened inter and intra family relationships (Irfan, 2003). Resultantly, conventional forms of social security failed to cater needs of economically dependent individuals and families (Vasavi (1999) as cited from Kabeer (2002). The above stated socio-economic conditions required formal and instutionlized arrangement of social secruity for fulfillment of needs of individuals and groups unable to maintain consumtion level as stated by Desai and Rudra, (2019) that after global economic crisis of 2007, social protection received attention as a prominent policy agenda for overcoming poverty and vulnerability.

\section{Social Insurance Programmes in Pakistan}

Until 2007, social protection programmes in Pakistan were either contributory for formal sector employees or Zakat, Bait ul Mal and informal transfers from family members and relatives. In 2007, with the assistance of The World Bank, national social protection strategy was designed, and Benzir Income Support Programme (BISP) was launched as largest programme of this type in the history of the country. The aim of this flagship programme was protecting chronically poor population and those vulnerable to poverty and increasing their consumption. The BISP has been renamed as Ehsas Programme (Zahid and Mumtaz, 2021). There are number of factors that contributed towards development of social protection in developing countries. Major among them include widening gap of income, any foreseen social unrest and addressing poverty among elderly population (Nikolov \& Bonci, 2020). In the Pakistan, social insurance programmes are only meant for formal sector employees. 
Formal sector is divided into two main categories; 1) public funded and 2) privately (personally) funded. The public sector employees are further classified into civil and military personnel. The civil employees are further divided into gazetted and non-gazetted cadre. In Pakistan, out of 7 million elderly population, only 0.85 million is covered by any of the social protection provisions (Ashiq \& Asad, 2017). As stated by Uzam and Asad (2017), there is politics of poverty in Pakistan and any measure taken towards its reduction and elimination including social protection programme is massively publicized by sitting governments (Hassan, 2015). Beneficiaries of social protection programmes are made believe that such provisions are privilege being offered to them not as citizen right. Despite massive advertisement on electronic and print media, ground realities are bitter because there is limited outreach of social protection programmes and only a small number of eligible beneficiaries can get benefits from them (Hassan 2015).

Researchers such as Irfan (2003) believed that industrialization and associated rural to urban migration weakened the family structure resulting into exclusion of elder people. A new class of 'able bodied poor' are excluded and incapacitated to participate in the productive work to augment their income. The author further added that in Pakistan, Mosque, state, NGOs, financial institutions, and private transfers are sources of social security under the following categories:

1. Social security programmes for workers (formal sector employees)

2. Pension for government servants.

3. Employees old age benefits programmes such as pension in the formal private sector.

4. Provincial social security benefits also include medical coverage, cash benefits and pensions, and other labour welfare measures for formal sector worker.

Whereas Word Bank (2007), divided current social protection programmes operative in Pakistan into two broader categories, 1) social safety nets and 2), social security. The former type helps household to cope with economic shocks for rehabilitation whereas latter provides prevention against risk of poverty and vulnerability. Likewise, Sayeed (2004) and Irfan (2003) elaborated the following types of social security programmes in Pakistan into following 9 categories:

1. Pension and Retirement Benefits (Old Age Support)

2. Other Private Sector Pension Plans (OPSPP)

3. Employees' Old Age Benefit Institution (EOBI)

4. Workers' Profit Participation Scheme (WPPS)

5. The Workers Welfare Fund (WWF)

6. Excise Duty on Minerals (Labour Welfare) Scheme, 1967

7. The Workers' Children Education Ordinance, 1972

8. Compulsory Group Insurance Scheme, 1968. 
9. Provincial Employees Social Security Scheme (PSSS)

10. Public Sector Benevolent Funds and Group Insurance

Government Pakistan initiated its first ever social security programme in the form of pension and gratuity in 1954 which was designed to target only permanent employees. That is why pension is considered as pioneer programme for social protection in Pakistan (Jamal, 2010).

Pakistan started provision of social protection to its formal sector employees in 1950s but it was only for permanent/regular employees whereas contractual employees were not eligible for it. Hence, being first ever social insurance programme in the history of country, pension is considered as oldest of social insurance programmes (Jamal, 2010).

There are several social insurance programmes meant for provision defined benefits to civil servants and those of armed forces. Generally, social insurance programmes include benefits like benevolent fund, pension, medical allowance, group insurance, housing and scholarships for children of civil servants and personnel of armed forces (Mahmood \& Nasir, 2008).

As mentioned earlier, social protection programmes are contributory by design and only target serving/retired employees of formal sector. Widley known and oldest of social insurance programmes is pension for eligibility criteria is either minimum 25 years of service or 60 years of age. A retired employees fulfilling given criteria is entitled for provident fund and monthly pension which is commuted against last withdrawn salary and length of service. Provident fund is financed from the employee's own contribution and addition from government whereas pension is provided from government allocated budget (Channa, 2012).

Table 2

Social Insurance Benefits for Public and Private Workers in Pakistan

\begin{tabular}{lcc}
\hline Nature of benefits & Public sector & Private sector \\
\hline Pension & $\checkmark$ & $\checkmark$ \\
Gratuity & $\checkmark$ & $\checkmark$ \\
Subsidized medical care & $\checkmark$ & $\checkmark$ \\
Subsidized housing & $\checkmark$ & $\mathrm{x}$ \\
Subsidized education for children & $\checkmark$ & $\mathrm{x}$ \\
Reservation of jobs for children & $\checkmark$ & $\mathrm{x}$ \\
Subsidized shops for employees & $\checkmark$ &
\end{tabular}

Source: Mahmood and Nasir (2008), updated by the author 


\section{Social Insurance as a Human Right}

Social protection is considered as basic human right guaranteed in a number of international conventions and treaties by UN agencies and several other international organizations/bodies. The Constitution of Pakistan clearly stipulates the provision of social protection to rank and file beyond caste, colour and creed (ShuHong et al., 2017).

Till date, an overwhelming majority of global population is not entitled/eligible for any of the social security benefits including contributory or non-contributory or social pension. Social security is meant for sustaining QOL of its recipients who have lost income due to old age, during work injuries, disease, disability or death. One of the critical factors obstructing provision of social security is financial stability and political will on the part of government in place. The ILO recommended minimum standards of social security benefits in 1952 (Seng, 2007; von Hauff, 2002).

The World Summit for Social Development (1995) stressed upon initiation and development of social security system as an integral component of social development and an effective instrument for fighting against various forms of poverty. The summit ended up with the political declaration of commitment of developing and implementing such policies which result into universal coverage of social protection for everyone and anyone who is out earning on the account of unemployment, disease, during pregnancy, in case of widowhood, old age or any type of disability. However, this undertaking has not be implemented in developing countries with letter and spirit due to numerous socio-economic factors.

\section{Method}

The current study aimed at measuring efficacy of social insurance for providing QOL to civil pensioners in Punjab Province. QOL of civil pensioners was measured in term of food, health and housing. A five-point Likert scale was constructed for measuring given dimensions of QOL of civil pensioners. Reliability of the research instrument was established through specialized statistical tests whereas validity of the contents and construct was ensured through experts of the field. The data were collected from each of the four regions of Punjab Province named as Northern, Sothern, Western and central Punjab. The respondents of the study were non-gazetted civil pensioners who retired at least two years before. Data were collected from 358 respondents through multistage sampling technique. Descriptive statistics and Pearson Corelation Analysis were performed for measing efficacy of social insurance (monthly pension) in providing perceived QOL to the civil pensioners. All the results of descriptive statistics and Pearson Corelation Analysis were displayed in the tabulated form.

\section{Results}

Table 3 


\section{Quality of Life (Food)}

\begin{tabular}{llllllll}
\hline Items & $\begin{array}{l}\text { Strongly } \\
\text { disagree\% }\end{array}$ & $\begin{array}{l}\text { Disagree } \\
\%\end{array}$ & $\begin{array}{l}\text { Neither } \\
\text { agreed not } \\
\text { disagreed } \\
\%\end{array}$ & $\begin{array}{l}\text { Agree } \\
\%\end{array}$ & $\begin{array}{l}\text { Strongly } \\
\text { agree\% }\end{array}$ & Mean & $\begin{array}{l}\text { Std. } \\
\text { Deviation }\end{array}$ \\
\hline $\begin{array}{l}\text { Purchasing } \\
\text { staple food }\end{array}$ & 3.6 & 6.5 & 24.6 & 48.6 & 15.9 & 3.09 & .935 \\
$\begin{array}{l}\text { Purchasing } \\
\text { expensive } \\
\text { food such as } \\
\text { meat }\end{array}$ & 9.5 & 16.8 & 47.2 & 22.3 & 4.2 & 3.00 & .761 \\
$\begin{array}{l}\text { Supplementin } \\
\text { food with }\end{array}$ & 5.0 & 15.6 & 53.9 & 19.8 & 5.3 & 2.94 & .671 \\
$\begin{array}{l}\text { seasonal } \\
\text { fruits }\end{array}$ & & & & & & & \\
$\begin{array}{l}\text { Affordability } \\
\text { of particular } \\
\text { food } \\
\text { prescribed by } \\
\text { doctor }\end{array}$ & 8.1 & 21.5 & 41.3 & 22.1 & 7.0 & 2.96 & .786 \\
\hline
\end{tabular}

The Table 3 contains responses about affordability of food as an important part of QOL. The results show that $48.6 \%$ of respondents were able to pay for purchasing basic food items. However, $10 \%$ of the respondents reported that they were unable to pay for staple food. According to $26.5 \%$ respondents, they were unable to purchase supplementary food items such as meat. $20.6 \%$ of the respondents could afford to buy seasonal fruit whereas $29.1 \%$ were able to purchase specialized food items prescribed by doctor whereas same percentage of respondents was unable to purchase particular food suggested by doctor.

Table 4

Quality of Life (Health)

\begin{tabular}{|c|c|c|c|c|c|c|c|}
\hline Items & $\begin{array}{l}\text { Strongl } \\
\mathrm{y} \\
\text { disagree } \\
\%\end{array}$ & $\begin{array}{l}\text { Disagree } \\
\%\end{array}$ & $\begin{array}{l}\text { Neither agreed } \\
\text { not disagreed } \%\end{array}$ & Agree $\%$ & $\begin{array}{l}\text { Strongl } \\
\mathrm{y} \\
\text { agree } \%\end{array}$ & $\begin{array}{l}\text { Mea } \\
\mathrm{n}\end{array}$ & $\begin{array}{l}\text { Std. } \\
\text { Deviation }\end{array}$ \\
\hline
\end{tabular}

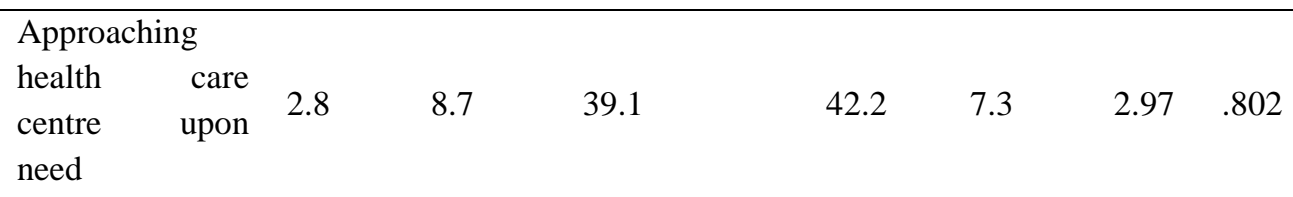




\begin{tabular}{|c|c|c|c|c|c|c|c|}
\hline $\begin{array}{l}\text { Affordability } \\
\text { for authorized } \\
\text { health care } \\
\text { centre }\end{array}$ & 4.2 & 26.0 & 34.6 & 30.2 & 5.0 & 2.89 & 789 \\
\hline $\begin{array}{l}\text { Affordability } \\
\text { for a specialist } \\
\text { doctor } \\
\text { need }\end{array}$ & 14.2 & 31.8 & 16.8 & 7.0 & 1.7 & 2.75 & .814 \\
\hline $\begin{array}{l}\text { Affordability to } \\
\text { buy all } \\
\text { prescribed } \\
\text { medicines from } \\
\text { pocket }\end{array}$ & 8.4 & 24.6 & 39.4 & 21.5 & 6.1 & 2.84 & .769 \\
\hline $\begin{array}{l}\text { Affordability to } \\
\text { get your check } \\
\text { up regularly (as } \\
\text { its age } \\
\text { requirement) }\end{array}$ & 22.3 & 36.6 & 21.8 & 15.4 & 3.9 & 2.85 & .854 \\
\hline $\begin{array}{l}\text { Skipping doctor } \\
\text { visit to lack of } \\
\text { money }\end{array}$ & 8.1 & 18.2 & 33.5 & 35.2 & 5.0 & 2.83 & .762 \\
\hline
\end{tabular}

The Table 4 shows data on QOL of respondents in term of their access to quality healthcare service in case they needed the same. The data shows that almost $50 \%$ of the respondents. In the opinion of $46 \%$ respondents, they were unable to access specialist doctor in case of need. Likewise, $33 \%$ of respondents were unable to buy all the medicines prescribed by the doctor. $40.2 \%$ of the respondents opined that they do not need to skip a planned visit to the doctor because of finance.

Table 5

Quality of Life (Housing)

\begin{tabular}{|c|c|c|c|c|c|c|c|}
\hline Items & $\begin{array}{l}\text { Strongl } \\
\mathrm{y} \\
\text { disagre } \\
\mathrm{e} \%\end{array}$ & $\begin{array}{l}\text { Disagree } \\
\%\end{array}$ & $\begin{array}{l}\text { Neither } \\
\text { agreed } \\
\text { disagreed } \%\end{array}$ & $\begin{array}{ll} & \text { Agree } \\
\text { not } \% \\
\%\end{array}$ & $\begin{array}{l}\text { Strongl } \\
\mathrm{y} \\
\text { agree } \%\end{array}$ & Mean & $\begin{array}{l}\text { Std. } \\
\text { deviati } \\
\text { on }\end{array}$ \\
\hline $\begin{array}{l}\text { Satisfaction } \\
\text { with number of } \\
\text { rooms }\end{array}$ & 10.1 & 31.6 & 17.3 & 33.8 & 7.3 & 2.88 & .861 \\
\hline $\begin{array}{l}\text { Satisfaction } \\
\text { with facilities } \\
\text { at home }\end{array}$ & 20.7 & 34.9 & 22.6 & 19.0 & 2.8 & 2.82 & .778 \\
\hline
\end{tabular}




\begin{tabular}{|c|c|c|c|c|c|c|c|}
\hline $\begin{array}{l}\text { Satisfaction } \\
\text { with condition } \\
\text { of and facilities } \\
\text { at kitchen }\end{array}$ & 10.9 & 29.9 & 31.0 & 24.3 & 3.9 & 2.90 & .798 \\
\hline $\begin{array}{l}\text { Satisfaction } \\
\text { with privacy at } \\
\text { home }\end{array}$ & 5.6 & 26.8 & 15.9 & 39.7 & 11.7 & 2.91 & .835 \\
\hline $\begin{array}{l}\text { Availability of } \\
\text { indoor toilet }\end{array}$ & 4.2 & 8.4 & 18.4 & 53.4 & 15.6 & 3.00 & .792 \\
\hline $\begin{array}{l}\text { Satisfaction } \\
\text { with location of } \\
\text { home }\end{array}$ & 4.7 & 19.0 & 26.3 & 43.0 & 7.0 & 2.92 & .794 \\
\hline
\end{tabular}

The Table 5 is about QOL of respondents in term of housing. According to table, $41.1 \%$ of the respondents were satisfied with number of rooms in their homes. More than half $(55.6 \%)$ of the respondents were not satisfied with facilities within in their homes. When asked about, satisfaction with privacy at home, $51.4 \%$ of the respondents reported their satisfaction, similarly $50 \%$ of them were also satisfied with location and neighbourhood of their home.

Table 6

Correlations Results of QOL with Social Insurance (Monthly Pension and Gratuity)

\begin{tabular}{llll}
\hline Description & & Monthly Pension & Gratuity \\
\hline \multirow{4}{*}{ Food } & Pearson Correlation & $.795^{* *}$ & $.636^{* *}$ \\
& Sig. (2-tailed) & .000 & .000 \\
& & & \\
\multirow{3}{*}{ Health } & Pearson Correlation & .841 & $.681^{* *}$ \\
& Sig. (2-tailed) & .000 & .000 \\
Housing & Pearson Correlation & $.812^{* *}$ & .676 \\
& Sig. (2-tailed) & .000 & .000 \\
\hline \multicolumn{4}{l}{} \\
& $* *$ Correlation is significant at the 0.01 level (2-tailed).
\end{tabular}

The Table 6 represents results of correlation and shows that monthly pension was positively and significantly correlated with food comprising the value of .796. Similarly, monthly pension was significantly and positively related with health (.842). Likewise, results of monthly pension and housing were also found positive and significant containing the value of .813 . 


\section{Discussion}

The main objective of this study was measurement of sufficiency of social insurance for maintaining QOL of non-gazetted civil pensioners in Pakistan. Pakistan, being one of the developing countries which still did not have offered universal social protection to all of its non-earning citizens. Social insurance benefits are contributory, so during service employees contribute a defined proportion of their income to state as their part; in return they are paid social insurance when they are unemployed on temporary or permanent basis (Antonopoulos, 2013). Based on this description, first ever social security programme was launched for government servants in early 1950s, soon after existence of Pakistan. It was followed by a number of different social protection iniatives but all of them were meant to support only formal sector employees. As of result of the skewness of social protection towards formal sector employees, they are able to live above poverty line and are able to maintain minimum QOL because of social insurance benefits. The results of the study revealed that majority of the non-gazetted civil pensioners were able to keep minimum QOL with financial support of monthly pension. The findings of the current study are concurrent with Azeem et al., (2019) who stated that social protection programmes have played a vital role in overcoming poverty and reducing vulnerability in Pakistan. It is because social protection programmes provide direct and indirect benefits to the programme beneficiaries and they are able to sustain minimum acceptable consumption level.

It has been enshrined in the 1973 Constitution of Pakistan that state shall provide basic needs including food, health, education and shelter (housing) to all the citizens across the board. However, till date it has failed to keep this constitutional commitment with its citizens as informal sector employees and workers such as agriculture, construction, transportation and daily wagers working in width and length of the country. As ascertained by Chohan, (2021), the major reasons for lack of an overarching social protection mechanism in Pakistan is lack of economic resources and large-scale informal sector. Because of poor fiscal net, tax collection is very low, that is why spending on social protection is highly dependent on foreign donations and loans. This state of affairs affects potential of the country for provision of social protection benefits to the poor or those prone to poverty. As long as majority of population is not brought into tax net, it would be nearly impossible for the government to pay generous social protection benefits including pension. Until 2008, when Benazir Income Support Programme (BISP) was launched, there was no nationwide and comprehensive non-contributory social protection programme for informal sector employees except Zakat, Pakistan Baitul Mal and informal transfers under the title of Sadqa and Fitra. The Current Government has expanded coverage and benefits of this universal social protection programme under the title of Ehsas-e-Kifalat.

The results of inferential statistics showed that all the studied aspects of QOL i-e food, health and housing were statistically significant with social 
insurance. The findings of study are consistent with Hidrobo et al., (2018) who found that social protection provisions enhance food consumption of beneficiaries in term of both quality and quantity. As maintained by Heltberg and Del Ninno (2006), although existing social protection programmes are fragmented and ad hoc based, hence provsion of social protection benefits is inadqeqauet and inconsistent. However, civil pensioners receive a big chunk $(53.8 \%)$ of social protection benefits and are living a better life as compared to their counterparts in private sector or those who are out of the covergae of any social protection programme. According to World Bank (2007), public sector (both civil and military) employees receive more social insurance benefits than private ones, that is why QOL of civil servants is higher than those serving in private sector.

Pakistani culture is known for holding high moral values and attached high respect, regard and esteem for elderly persons. Elderly in the form of father, mother, uncle, aunts and grandparents were highly valued and enjoyed elevated social status. But with the passage of time, there has been seen rapid social change in centuries old social values and elderly are no longer that much highly valued people. Now elder parents/guardians are no more stakeholders in socio-economic decision making of a household (Ahmad et al., 2018). Based on this changing scenario, when familial ties are getting weaker and children are no more that source of socio-economic support for their elderly parents, need and necessity of social insurance become manifold. In the given social conditions, provision of social insurance in the form of monthly pension makes the civil pensioners economically independents and makes them feel less burden on their families. In the case of developing countries, because of fragmented nature of social insurance benefits, retired persons are susceptible to poverty and are living with scarce resources (Schwarz, 2003). As aforementioned, social insurance is contributory and based on earned benefits of the employees, however in developing countries these benefits are fragmented due to poor national economies and lesser attention on elderly wellbeing, this negligence results into increased poverty and vulnerability in case of any contingency (Barrientos, 2010).

\section{Conclusion}

The study aimed at measuring adequacy of social insurance benefits in maintaining QOL of non-gazetted civil pensioners. In this info-techno-digital world, familial ties are getting weaker and weaker and joint family system is being replaced with nuclear family system. Due to this cultural change, elderly citizen are on losing side as they are not enjoying the same status as they have been some 3-4 decades ago. Now, there are increasing cases of parents facing neglect in Pakistan and need for old care homes is being felt particularly in urban areas. In the given scenario, social insurance benefits are proving significant in maintaining acceptable QOL of civil pensioners. It is well documented that amount of social insurance (monthly pension) is not being increased with reference to inflation rate and skyrocketing prices of daily 
commodities but still provision of social insurance to civil pensioners is not less than a blessing. QOL of civil pensioners is better than retirees from private sector or under privileged class living with meagre economic resources.

\section{Acknowledgement}

The paper has been extracted from $\mathrm{PhD}$ thesis of first author, the thesis was submitted to Universiti Sains Malaysia, Malaysia.

\section{Reference}

Ahmad, R., Mi, H., Keyao, R., Khan, K., \& Navid, K. (2018). Aging and social security system in Pakistan: policy challenges, opportunities, and role of China-Pakistan Economic Corridor (CPEC). Educational Gerontology, 44(9), 537-550

Antonopoulos, R. (2013). Expanding social protection in developing countries: A gender perspective. Levy Economics Institute at Bard College Working Paper, 1-40.

Ashiq, U., \& Asad, A. Z. (2017). The rising old age problem in Pakistan. Journal of the Research Society of Pakistan-Vol, 54(2).

Azeem, M. M., Mugera, A. W., \& Schilizzi, S. (2019). Do social protection transfers reduce poverty and vulnerability to poverty in Pakistan? Household level evidence from Punjab. The Journal of Development Studies, 55(8), 1757-1783.

Barrientos, A. (2006). Development of a social protection strategy for Pakistan. Social Protection Projects at IDS. UK: Institute of Development Studies.

Barrientos, A. (2010). Social protection and poverty. Accessed from: https://www.unrisd.org/80256B3C005BCCF9/(httpPublications)/973B 0F57CA78D834C12576DB003BE255?OpenDocument\&cntxt=1A348 \&cookielang=es

Barrientos, A., \& Hulme, D. (2009). Social protection for the poor and poorest in developing countries: reflections on a quiet revolution: commentary. Oxford Development Studies, 37(4), 439-456.

Channa, A. (2012). Social protection in Pakistan: a profile of existing programmes and an assessment of data available for analysis. Background paper, Asia Research Centre, London School of Economics, UK.

Chohan, U. W. (2021). Directions for Pensions in Pakistan. Accessed from: https://papers.ssrn.com/sol3/papers.cfm?abstract_id=3761405.

Deacon, B. (2013). Global social policy in the making: The foundations of the social protection floor. Policy Press. 
Desai, R. M., \& Rudra, N. (2019). Trade, poverty, and social protection in developing countries. European Journal of Political Economy, 60, 101744.

DeWitt, L. (2010). The development of social security in America. Social Security Bulletin, 70(3), 1-26.

Dixon, J. (2001). A global perspective on social security programs for the unemployed. International Social Work, 44(4), 405-422.

Feldstein, M, \& Liebman, J, B. (2002). Social security. Handbook of public economics, 4, 2245-2324.

Government of Pakistan (2008). National social protection strategy, Centre for poverty reduction and income distribution. Islamabad, Pakistan: Planning Commission.

Guhan, S. (1992). Social security in India: Looking one step ahead. Poverty in India. Research and policy, 2(8), 36-52.

Hassan, S. M. (2015). Making an impact analysis of social protection programs in Pakistan. Journal of the Research Society of Pakistan, 52(1).

Hidrobo, M., Hoddinott, J., Kumar, N., \& Olivier, M. (2018). Social protection, food security, and asset formation. World Development, 101, 88-103.Development, 101, 88-103.

Irfan, M. (2003). Poverty and social safety nets: a case study of Pakistan. Retrieved from: http://pide.org.pk/Mimap/Report15.pdf

Jamal, H. (2010). A profile of social protection in Pakistan: An appraisal of empirical literature. Retrieved from: http://www.spdc.org.pk/Data/Publication/PDF/RR81.pdf

Kabeer, N. (2002). Safety nets and opportunity ladders: Addressing vulnerability and enhancing productivity in South Asia. Development Policy Review, 20(5), 589-614.

Kabeer, N., Mumtaz, K., \& Sayeed, A. (2006). Citizenship and social protection: Towards a transformative agenda for Pakistan. Report for $A D B$ and DFID, Islamabad, Pakistan. Retrieved from: https://www.protocols.io/article/citizenship-and-social-protectiontowards-a-tr-by-naila-kabeerkhawar-m-citizenship-and-soci1000251372 .

Nikolov, P., \& Bonci, M. (2020). Do public program benefits crowd out private transfers in developing countries? A critical review of recent evidence. World Development, 134, 104967.

Mahmood, N., \& Nasir, Z. M. (2008). Pension and social security schemes in Pakistan: Some Policy Options (No. 22211). East Asian Bureau of Economic Research.

Midgley, J. (2010). The role of social security in poverty alleviation: An international review. Social Policy and Poverty in East Asia: The role of social security, 16-44.

Mumtaz, Z., \& Whiteford, P. (2021). Comparing formal and informal social protection: a case study exploring the usefulness of informal social 
protection in Pakistan. Journal of International and Comparative Social Policy, 37(3), 243-272.

Mumtaz, Z., \& Whiteford, P. (2017). Social safety nets in the development of a welfare system in Pakistan: An analysis of the Benazir Income Support Programme. Asia Pacific Journal of Public Administration, 39(1), 16-38.

Sayeed, A. (2004). Social protection in Pakistan: concept, situation analysis and the way forward. Islamabad: Center for research on poverty reduction and income distribution, working paper, 5.

Schwarz, A. (2003). Old age security and social pensions. World Bank: Human Development (Social Protection) Hub: Processed.

Seng, S. C. (2007). Social security: Concept and reality with reference to Malaysia. Malaysia Labour Review, 1(1). 1-10.

ShuHong, Y., Din, M., \& Ranjha, K. (2017). Social protection schemes in Pakistan: an assessment of existing program. Academic Journal of Business, Administration, Law and Social Sciences, 3(2).

Tamborini, C. R., \& Cupito, E. (2012). Social insurance and children: The relationship between social security, economic well-being, and family context among child recipients. Journal of Children and Poverty, 18(1), $1-22$.

Van Ginneken, W. (2003). Extending social security: Policies for developing countries. Int'l Lab. Rev., 142, 277.

Vasavi, A. R. (1999a) Harbingers of Rain. Land and Life in South India. Oxford: Oxford University Press.

von Hauff, M. (2002). The relevance of social security for economic development. Social Protection in Southeast and East Asia, Singapore: FES. Retrieved from: library.fes.de/pdf-files/iez/01443002.pdf

Weigand, C., \& Grosh, M. (2008). Levels and patterns of safety net spending in developing and transition countries (No. 0817). SP Discussion Paper.

The World Bank. (2021). World development indicators. World Bank database. Available at http://www.data.worldbank.orgdatabase

The World Bank. (2007). Social protection in Pakistan managing household risks and vulnerability: Managing household risks and vulnerability (Report No. 35472-PK). 